\title{
Estimation of Potential of Agriculture Biogas Production in the Biała Podlaska County (Poland)
}

\author{
Alina Kowalczyk-Juśko', Klaudia Mazur², Michał Maciąg² , Patrycja Pochwatka1, \\ Agnieszka Listosz ${ }^{1}$, Andrzej Mazur ${ }^{1}$
}

1 University of Life Sciences in Lublin, Department of Environmental Engineering and Geodesy, Leszczyńskiego 7, 20-069 Lublin, Poland

2 University of Agriculture in Krakow, Faculty of Environmental Engineering and Land Surveying, Mickiewicza 24/28, 30-059 Kraków, Poland

* Corresponding author's e-mail: amazur70@op.pl

\begin{abstract}
By analyzing the resources of the economic infrastructure (distilleries, diaries, fruit and vegetable processing and meat processing factories) of the Biała Podlaska County, the possibilities of the biomass obtaining and creating the biogas plants basing on the agri-food industry waste were estimated. The stocking of animals was the basis for the assessment of manure and slurry resources that can be subjected to the methane fermentation process. On the basis of the data concerning the surface of the wastelands, located on the Biała Podlaska County territory, the possibilities of the biomass from special crops were specified. In the Biała Podlaska County, it was established that there are possibilities for obtaining the biomass for the biogas production: from livestock production (1 $475272 \mathrm{GJ} /$ year), maize cropping in marginal lands (172 $875 \mathrm{GJ} /$ year) and wastes and by-products from food industry (51 $081 \mathrm{GJ} /$ year). The estimated potential of biogas allows for the construction of several agricultural biogas plants with a capacity of $1 \mathrm{MW}_{\mathrm{e}}$ each, often built in Poland. The usage of the identified resources enabling the improvement of the energetic safety and also can contribute to the sustainable development of rural areas and agriculture.
\end{abstract}

Keywords: renewable energy sources, biogas, biogas plant, substrates

\section{INTRODUCTION}

The development of civilization, the increase in energy demand, with the simultaneous decrease in fossil energy resources force the search for alternative solutions in the form of renewable energy sources (RES) [Czekała et al., 2018].

The importance of renewable energy sources for the energy security of regions and the country is continuously growing, and their additional advantage is the improvement of the energy supply to the areas with poor energy infrastructure [Bigili et al., 2017]. The use of renewable energy sources has social, economic, and environmental effects, most of which are beneficial, provided that eco-energy systems are planned and used rationally [Ramos-Suárez, 2019; Safieddin Ardebili, 2020].
Energy planning on a commune, county or voivodship level is an essential element of the development of this sector, because the wrong location of the investment may arouse social protests, generate high costs - primarily related to the transport of raw materials, and also cause the emissions (noise, pollution, exhaust fumes), which will affect the deterioration of the quality of the environment [Piwowar et al., 2016].

In Poland, the use of biomass for the production of electricity and heat has the largest share in the matrix of RES [Dach et al., 2014]. Biomass can be used in thermochemical processes (combustion, gasification, pyrolysis) or biochemical processes, such as anaerobic fermentation, during which biogas is produced [Nunes et al., 2020]. Biogas is a mixture of gases, commonly forming in the environment, arising in the anaerobic 
digestion process. This process is basically wellknown; however, within the last years many scientists have used advanced computer methods (including artificial intelligence) in order to model and control this phenomena -this is a typical tendency not only in the RES area but also in environmental protection and agronomy [Janczak et al., 2013; Dach et al., 2016]. The basic substrates used in an agricultural biogas plant are natural fertilizers (e.g., slurry, chicken manure, etc.), vegetable silages, and by-products of the agri-food industry [Niemczyk et al., 2016].

The article estimates the biomass resources available in the Biała Podlaska County, which can be used for biogas production, without the risk of disturbing the land resources for food and feed production, as it is often emphasized in the literature [Czekała, 2018; Pochwatka et al., 2020].

\section{MATERIAL AND METHODS}

This article contains the results of research carried out in the Biała Podlaska County (Lubelskie Voivodeship, Poland). The methodology was described in [Listosz et al., 2017], and the resources of solid biomass were estimated by Kowalczyk-Juśko et al., [2020]. The information was obtained from the surveys in communes and the data from the Bank of the Local Data [GUS], the Agency for Restructuring and Modernisation of the Agriculture, the District Veterinary Officer of Biała Podlaska and the Marshal Office of the Lubelskie Voivodeship. On tha basis of these data, the biomass sourcing possibilities and the availability of the substrates for the biogas production in the Biała Podlaska County were estimated.

The study of the by-products and the waste arising in agriculture as well as the agri-food industry was carried on to describe the potential production of the biogas and estimate its capacity from different sources. In the paper, the potential of the maize biomass planted for energy purposes was also estimated.

The research was based on the methods of estimation the regional resources of the biomass for the energetic purposes, specified by KowalczykJuśko [2010] and Kościk and KowalczykJuśko [2011].

\section{RESULTS AND DISCUSSION}

The resources of by-products and waste, arising from the agriculture, the agri-food industry, the composition of which allows processing them in biogas plants, were taken into consideration. Particular sources of the biogas are essentially different from the others and the analysis of them was therefore processed separately. The resources possible to use in agricultural biogas plants are such materials as: natural fertilizers (slurry, manure), agricultural industry waste, and cultivated plants, especially maize.

\section{Animals manure and slurry}

Animal manure is the dominant group of substrates for agricultural biogas plants in Poland [KOWR, 2020]. In order to determine the possibility of biogas production from these substrates in the studied County, the number of farm animals in physical units was inventoried and converted into livestock units, following the Regulation [2019]. Over 60.7 LSU (Livestock Unit equal to $500 \mathrm{~kg}$ ) farm animals were inventoried in the Biała Podlaska County: cattle, pigs, and poultry (Tab. 1). Approximately 3.7 thousand horses and over 5 thousand heads of sheep and goats (in total) were found, but these groups of animals were not included in the calculations, since these numbers are not significant. Moreover, they are

Table 1. The potential of biogas from manure and slurry

\begin{tabular}{|c|c|c|c|c|}
\hline Specification & Unit & Cattle & Swine & Poultry \\
\hline Amount of physical pieces & pcs. & 56587 & 131698 & 13726159 \\
\hline Amount of LSU & pcs. & 46776 & 39509 & 54905 \\
\hline Amount of LSU in farms under vet control* & pcs & 5795 & 8429 & 46504 \\
\hline Unitary efficiency of biogas** & $\mathrm{Nm}^{3} /$ LSU/year & 589 & 339 & 1369 \\
\hline Biogas potential & $\mathrm{Nm}^{3} /$ year & 3413255 & 2857431 & 63663976 \\
\hline Content of biomethane & $\%$ & 60 & 60 & 59 \\
\hline Biomethane potential & $\mathrm{Nm}^{3} /$ year & 2047953 & 1714459 & 37561746 \\
\hline
\end{tabular}

* data from District Inspectorate of Veterinary in Biała Podlaska

** - source: Klugmann-Radziemska 2009 
mostly kept on litter in small numbers, so these faeces do not represent a significant potential for biogas plants. Moreover, cattle, pigs, and poultry on many farms are reared under the conditions where it is not possible to obtain manure for biogas production (a small number of animals, grazing animals on pastures, frequent removal of manure to the fields as natural fertilizers).

The focus was placed on large farms under veterinary control to determine the real amount of manure and slurry useful for biogas production. On the basis of the data from the District Inspectorate of Veterinary in Biała Podlaska, it was calculated that the number of LSUs in cattle, pigs, and poultry is 5795,8429 , and 46504 units, respectively. The theoretical amount of biomethane from these animals' faeces is in total $41324158 \mathrm{Nm}^{3} /$ year (Tab. 1). The high potential of biogas that can be obtained from poultry farms is noteworthy. This production is very developed in the studied region (including poultry farms and slaughterhouses). The poultry manure is a nuisance waste from production due to the unpleasant odor, which can be eliminated or at least reduced by methane fermentation [Anjum et al., 2017]. At the same time, these waste products have a high unit biogas capacity, although their fermentation is not easy, due to the high content of ammonia and ash [Markou, 2015; Janczak et al., 2017].

\section{Biogas from agri-food industry}

Besides the livestock production, there is a significant potential for biogas production in the plants processing the products of agricultural origin, including sugar factories, distilleries, breweries, dairies, malt barns, meat industry, fruit and vegetable processing, fodder production, gelatin production, fish processing, production of vegetable and animal fat, etc. These plants were inventoried [Listosz et al. 2017], the type and amount of waste and by-products generated during the year were also determined. The organic waste from the food industry (e.g., fruit and vegetable waste, dairy waste, stillage, spent grain, beet pulp from the sugar industry) have a high energy potential, and they are a low-budget resource for the biogas plants as in many cases the disposal of them would be expensive for the producers. An example of this kind of waste may be slaughterhouse by-products, containing animal masseters, blood, fat remains. Especially, the food processing plants are supposed to be interested in the management of their waste. Pursuant to the low regulations, depositing this waste in landfills is prohibited [Act... 2012].

On the basis of the inventoried amounts of the waste from the agri-food industry in the Biała Podlaska County, the potential of the biogas from the waste was estimated. The results of the estimation were reported in Table 2.

In the Biała Podlaska County, there are nine types of biodegradable waste. It was found that three of them are dominate resources: pomace, must and after-digestion sludge, stillage; industrial water treatment plant sludge (provided they are collected separately from urban wastewater in accordance with the regulations [Act... 2015]) and raw materials and products, not suitable for consumption and processing. In total, there was over $58,000 \mathrm{Mg}$ of biodegradable waste, suitable for biogas production, yearly collected (Tab. 2). The estimated amount of the processable waste may be enough to produce almost 1,500,000 $\mathrm{Nm}^{3}$ of biomethane. It is, however, necessary to consider that over $90 \%$ of the estimated potential origins from the waste, labeled with '02 0780 ' code (pomace, must and after-digestion sludge, stillage).

\section{Silage from special crops}

The cultivated plants silage may be a supplement for substrates for the agricultural biogas production. The silage from whole maize plants is used most commonly, as this plant does have low soil requirements, it gives a high harvest and the efficiency of biogas is high. In order to minimize the competition between the production of energy crops and those grown for feed and consumption, it is recommended to locate energy crops on lowquality land where traditional crops are not profitable. In order to estimate the potential resources of maize to use by biogas plants, it was assumed that it would be planted on the $10 \%$ of inventoried area of marginal grounds $(5,6,8,9$ complexes of agricultural soil suitability). Such lands occupy approximately 12.2 thousand hectares in the Biała Podlaska County [Kowalczyk-Juśko et al. 2020]. The following parameters of maize biomass were adopted for the calculations: yield $-45.7 \mathrm{Mg} / \mathrm{ha}$, d.m. content $-30 \%$, o.d.m. content $-95 \%$ in d.m., biogas efficiency $-575 \mathrm{Nm}^{3} / \mathrm{Mg}$ o.d.m., methane content in biogas - 53\% [Kowalczyk-Juśko et al. 2015]. It was calculated that, on average, in the 
Table 2. The potential of the biogas from the agri-food industry

\begin{tabular}{|c|c|c|c|c|c|c|}
\hline \multirow[t]{2}{*}{ Territory unit } & \multirow[t]{2}{*}{$\begin{array}{l}\text { Code of } \\
\text { waste }^{*}\end{array}$} & $\begin{array}{l}\text { Waste } \\
\text { amount }\end{array}$ & $\begin{array}{l}\text { Content of } \\
\text { dry matter } \\
\text { (d.m.) }\end{array}$ & $\begin{array}{l}\text { Content of } \\
\text { organic d.m. }\end{array}$ & $\begin{array}{l}\text { Efficiency of } \\
\mathrm{CH}_{4}^{* *}\end{array}$ & $\begin{array}{l}\text { Biomethane } \\
\text { potential }\end{array}$ \\
\hline & & $\mathrm{kg}$ & $\%$ & $\%$ d.m. & $\mathrm{Nm}^{3} / \mathrm{kg}$ o.d.m. & $\mathrm{Nm}^{3}$ \\
\hline $\begin{array}{l}\text { Międzyrzec Podlaski (urban } \\
\text { commune) }\end{array}$ & 020204 & 3100830 & 0.03 & 0.90 & 0.45 & 37675 \\
\hline \multirow{2}{*}{ Międzyrzec Podlaski (rural commune) } & 020202 & 151230 & 0.20 & 0.80 & 0.43 & 10405 \\
\hline & 020204 & 3090942 & 0.03 & 0.90 & 0.45 & 37555 \\
\hline Biała Podlaska (rural commune) & 020380 & 42000 & 0.30 & 0.90 & 0.38 & 4309 \\
\hline \multirow{2}{*}{ Janów Podlaski } & 020304 & 3600 & 0.15 & 0.80 & 0.45 & 194 \\
\hline & 020380 & 22600 & 0.30 & 0.90 & 0.38 & 2319 \\
\hline Konstantynów & 020780 & 7271 & 0.08 & 0.83 & 0.38 & 184 \\
\hline \multirow{4}{*}{ Leśna Podlaska } & 020101 & 42000 & 0.04 & 0.92 & 0.33 & 510 \\
\hline & 020780 & $\begin{array}{c}51024 \\
000\end{array}$ & 0.08 & 0.83 & 0.38 & 1287438 \\
\hline & 020304 & 860900 & 0.15 & 0.80 & 0.32 & 33059 \\
\hline & 020380 & 117000 & 0.30 & 0.90 & 0.38 & 12004 \\
\hline \multirow{4}{*}{ Rossosz } & 020106 & 16000 & 0.15 & 0.80 & 0.27 & 518 \\
\hline & 020202 & 57200 & 0.20 & 0.80 & 0.43 & 3935 \\
\hline & 020203 & 30 & 0.20 & 0.80 & 0.43 & 2 \\
\hline & 020281 & 10550 & 0.20 & 0.80 & 0.43 & 726 \\
\hline \multicolumn{2}{|l|}{ Total } & $\begin{array}{c}58546 \\
153\end{array}$ & - & - & - & 1430833 \\
\hline
\end{tabular}

* - waste codes according to: Act... 2012.

** - source: Wittmaier M. 2003.

study area, $55754 \mathrm{Mg}$ of fresh biomass can be collected, from which, after ensilage, 9,136,687 $\mathrm{Nm}^{3}$ biogas $\left(4,842,444 \mathrm{Nm}^{3}\right.$ of biomethane) can be obtained. This potential is only theoretical, as the cultivation of plants for the energy purposes depends on the sales market and the price relationship between energy biomass and the yields of plants grown for food and fodder.

\section{Energy potential from biogas in Biała Podlaska County}

The calorific value of methane of $35.7 \mathrm{MJ} / \mathrm{Nm}^{3}$ was used to calculate the amount of Energy obtainable in the study area. The estimations carried out, concerning the different types of substrates used for the biogas production proved that the livestock does have the highest energy potential
- almost $1.5 \mathrm{mln}$ GJ (Tab. 3). Considering a supplement of special crops (e.g., maize silage), this potential may be significantly higher. A third, significant source of the biogas may be the agrifood industry waste [Garcia et al., 2019], which enables to obtain about 51 thousand GJ of energy each year. The potential of the biogas production from three agricultural sources enables to obtain almost $1.7 \mathrm{mln}$ GJ of energy (Fig. 1) and it differs in individual communes (Fig. 2).

Under the Polish conditions, an agricultural biogas plant, producing electricity and heat in cogeneration, with a capacity of $1 \mathrm{MW}_{\mathrm{e}}$ uses annually approximately 4 million $\mathrm{Nm}^{3}$ of biogas, containing approximately $50 \%$ of biomethane. Therefore, the estimated amount of biomethane that can be obtained from the substrates - most of which are currently available in the study area

Table 3. The potential of biogas end energy production from different types of waste in Biała Podlaska County

\begin{tabular}{|l|c|c|}
\hline \multirow{2}{*}{\multicolumn{1}{|c|}{ Specification }} & Nm³/year & GJ/year \\
\cline { 2 - 3 } & 41324158 & 1475272 \\
\hline From livestock production & 4842444 & 172875 \\
\hline From special crops & 1430833 & 51081 \\
\hline From agri-food waste & 47597435 & 1699228 \\
\hline Total & & \\
\hline
\end{tabular}




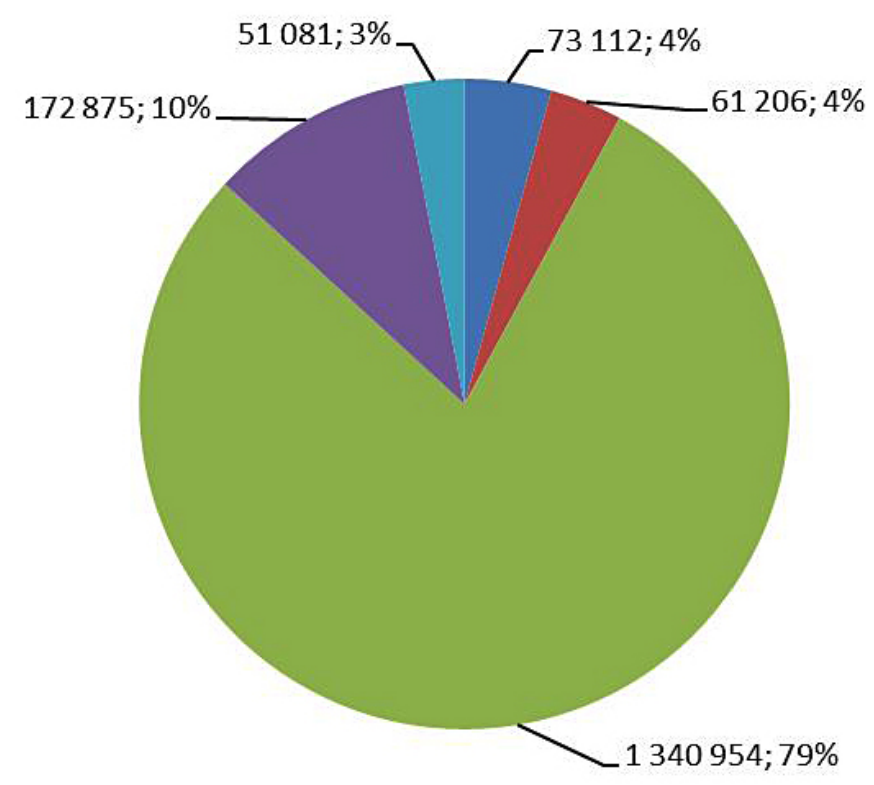

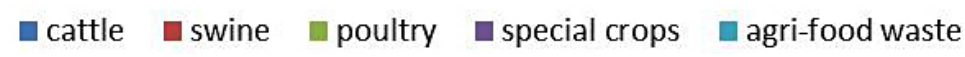

Figure 1. Biogas potential of energy (GJ) from different sources

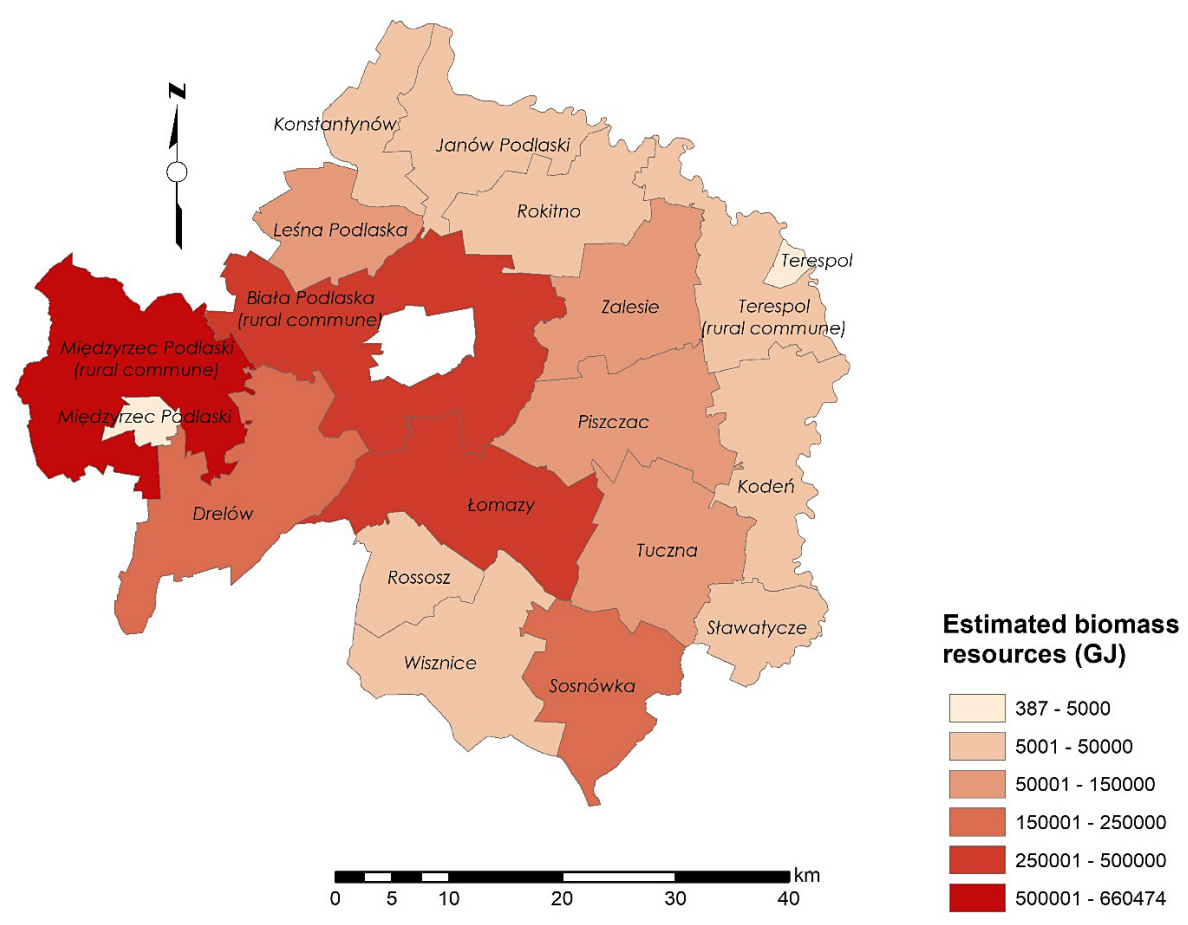

Figure 2. Estimated biomass resources (GJ) in communes of Biała Podlaska County

(except for maize biomass) - allows for the construction of several biogas plants with an average capacity of $1 \mathrm{MW}_{\mathrm{e}}$. Of course, these estimates are general; they do not take into account the efficiency of facilities, losses of raw materials and energy, etc. However, they allow determining the order of magnitude of available substrates and the development opportunities of this production sector.

\section{CONCLUSIONS}

1. According to the research, it was concluded that in the Biała Podlaska County there are important resources of the economic infrastructure (animal farms, alcohol factories, fruit and vegetable processing factories, meat processing factories), that may be a potential source of the waste, used for the biogas production. 
2. The estimated biogas potential was about 1.7 million GJ of energy per year, without affecting the nutritional safety of the region and the state. The highest potential for the biogas production is located in the poultry farms over 1.3 million GJ of the energy.

3. The most reasonable solution is to use biomass on a local scale, e.g., for electricity production, heating the municipal and individual buildings. The local usage of the resources enabling the improvement of the energetic safety and also the sustainable development of the rural areas and the agriculture.

\section{Acknowledgements}

Publication is funded by the Polish National Agency for Academic Exchange under the International Academic Partnerships Programme from the project „Organization of the $9^{\text {th }}$ International Scientific and Technical Conference entitled Environmental Engineering, Photogrammetry, Geoinformatics - Modern Technologies and Development Perspectives".

\section{REFERENCES}

1. Act of 14 December 2012 on the Waste. Journal of Laws, 2013 item 21 (in Polish).

2. Act of 15 February 2015 on Renewable Energy Sources, Journal of Laws 2020, item 261 (in Polish).

3. Anjum R., Grohmann E., Krakat N. 2017. Anaerobic digestion of nitrogen rich poultry manure: Impact of thermophilic biogas process on metal release and microbial resistances. Chemosphere, 168, 16371647. doi: 10.1016/j.chemosphere.2016.11.132.

4. Bilgili F., Koçak E., Ümit B., Kuşkaya S. 2017. Can biomass energy be an efficient policy tool for sustainable development? Renewable and Sustainable Energy Reviews, 71, p. 830-845. doi:10.1016/j. rser.2016.12.109.

5. Czekała W. 2018. Agricultural Biogas Plants as a Chance for the Development of the Agri-Food Sector. Journal of Ecological Engineering, 19 (2), 179-183. doi: 10.12911/22998993/83563.

6. Czekała W., Bartnikowska S., Dach J., Janczak D., Smurzyńska A., Kozłowski K., Bugała A., Lewicki A., Cieślik M., Typańska D., Mazurkiewicz, J. 2018. The energy value and economic efficiency of solid biofuels produced from digestate and sawdust. Energy, 159, 1118-1122. doi: 10.1016/j. energy.2018.06.090.

7. Dach J., Czekała W., Boniecki P., Lewicki A.,
Piechota, T. 2014. Specialised Internet Tool for Biogas Plant Modelling and Marked Analysing. Advanced Materials Research, 909, 305-310. doi:10.4028/www.scientific.net/amr.909.305.

8. Dach J., Koszela K., Boniecki P., Zaborowicz M., Lewicki A., Czekała W., Skwarcz J., Wei Qiao, Piekarska-Boniecka H., Białobrzewski I. 2016. The use of neural modeling to estimation the methane production from slurry fermentation processes. Renewable and Sustainable Energy Reviews, 56, 603-610. doi: 10.1016/j.rser.2015.11.093.

9. District Veterinary Officer of Biała Podlaska. Personal communication (Unpublished data).

10. Garcia N.H., Mattioli A., Gil A., Frison N., Battista F., Bolzonella D. 2019. Evaluation of the methane potential of different agricultural and food processing substrates for improved biogas production in rural areas. Renewable and Sustainable Energy Reviews, 112, 1-10. doi: 10.1016/j.rser.2019.05.040.

11. GUS [Online]. Bank Danych Lokalnych [Local Data Bank] Available: https://bdl.stat.gov.pl/BDL/ start. (Accessed: 17-Apr-2020) (in Polish).

12. Janczak D., Lewicki P., Mazur R., Boniecki P., Dach J., Pawlak M., Pilarski K., Czekała W. 2013. The Selected Examples of the Application of Computer Image Analysis in the Assessment of Environmental Quality. Fifth International Conference On Digital Image Processing (ICDIP 2013) Book Series: Proceedings of SPIE. Vol.: 8878 Article Number: 88783R. doi: 10.1117/12.2031069.

13. Janczak D., Malińska K., Czekała W., Cáceres R., Lewicki A., Dach J. 2017. Biochar to reduce ammonia emissions in gaseous and liquid phase during composting of poultry manure with wheat straw. Waste Management, 66, 36-45. doi: 10.1016/j. wasman.2017.04.033.

14. Klugmann-Radziemska E. 2009. Odnawialne źródła energii - przykłady obliczeniowe. Wyd. Politechniki Gdańskiej, Gdańsk (in Polish).

15. Kościk B., Kowalczyk-Juśko A. 2011. Metodyka obliczania lokalnego potencjału zasobów biomasy. [The methods of the estimation of a local potential of the biomass resources] In: Gospodarowanie energią $\mathrm{w}$ gminach - podstawy metodyczne [The energy management in the communes - the methods basics] Ed. H. Rusak. Białystok. Wyd. Wyższa Szkoła Ekonomiczna w Białymstoku. ISBN 978-83-61247-46-3, 127-186 (in Polish).

16. Kowalczyk-Juśko A. 2010. Metodyka szacowania regionalnych zasobów biomasy na cele energetyczne [Regional biomass resources for energy purposes (methodical problems)]. Zeszyty Naukowe SGGW w Warszawie. Ekonomika i Organizacja Gospodarki Żywnościowej, 85. 103-116 (in Polish).

17. Kowalczyk-Juśko A., Marczuk A., Dach J., Szmigielski M., Zarajczyk J., Jóźwiakowski K., Ko- 
walczuk J., Andrejko D., Ślaska-Grzywna B., Leszczyński N. 2015. Thermochemical and biochemical maize biomass conversion for power engineering. Przem. Chem. 94/2, 178-181. doi: 10.15199/62.2015.2.9

18. Kowalczyk-Juśko A., Listosz A., Mazur K., Maciąg M., Pochwatka P., Mazur A. 2020. The state and the perspectives of the eco-energy infrastructure development in Biała Podlaska County (Poland). Part II. Estimation of solid biomass resources for energy purposes. The 9th International Scientific-Technical Conference on Environmental Engineering, Photogrammetry, Geoinformatics - Modern Technologies and Development Perspectives (EEPG Tech 2019), Lublin, Poland, E3S Web of Conferences, Vol. 171, doi: 10.1051/e3sconf/202017101005.

19. KOWR, 2020 [Online]. Available: https://bip.kowr. gov.pl/uploads/pliki/oze/biogaz/ surowce_2019r. pdf. (Accessed: 18-Feb-2020) (in Polish).

20. Listosz A., Kowalczyk-Juśko A., Mazur A., Jóźwiakowski K., Gizińska-Górna M., Pytka A., Marzec M. 2017. The state and the perspectives of the ecoenergy infrastructure development in Biała Podlaska Country. Part I. State analysis. Water-EnvironmentRural Areas, T. 17, Z. 4 (60), 81-93 (in Polish).

21. Markou G. 2015. Improved anaerobic digestion performance and biogas production from poultry litter after lowering its nitrogen content. Bioresource Technology, 196, 726-730. doi: 10.1016/j. biortech.2015.07.067.

22. Nunes L.J.R., Causer T.P., Ciolkosz D. 2020. Biomass for energy: A review on supply chain management models. Renewable and Sustainable
Energy Reviews, 120, 109658. doi: 10.1016/j. rser.2019.109658.

23. Piwowar A., Dzikuć M., Adamczyk J. 2016. Agricultural biogas plants in Poland - Selected technological, market and environmental aspects. Renewable and Sustainable Energy Reviews, 58, 69-74. doi: 10.1016/j.rser.2015.12.153.

24. Pochwatka P., Kowalczyk-Juśko A., Mazur A., Janczak D., Pulka J., Dach J., Mazurkiewicz J. 2020. Energetic and Economic Aspects of Biogas Plants Feed with Agriculture Biomass. Proc. 2020 4th Int. Conf. Green Energy Appl. ICGEA 2020, Institute of Electrical and Electronics Engineers Inc.; 2020, 130-3. doi: 10.1109/ICGEA49367.2020.239705.

25. Ramos-Suárez JL, Ritter A, Mata González J, Camacho Pérez A. 2019. Biogas from animal manure: A sustainable energy opportunity in the Canary Islands. Renewable and Sustainable Energy Reviews, 104, 137-50. doi: 10.1016/j.rser.2019.01.025.

26. Regulation of the Council of Ministers of 10 September 2019 on projects that may significantly affect the environment, Journal of Laws 2019, item 1839 (in Polish).

27. Safieddin Ardebili SM. 2020. Green electricity generation potential from biogas produced by anaerobic digestion of farm animal waste and agriculture residues in Iran. Renewable Energy, 154, 29-37. doi: 10.1016/j.renene.2020.02.102.2020.239705.

28. Wittmaier M. 2003. Co-fermentation of organic substrates in the decentralized production of regenerative energy. Workshop "Technology of Municipal Waste Treatment-Experiences and Challenges", Hanoi University of Science, Vietnam. 